\title{
Control of Postharvest Botrytis Fruit Rot with Preharvest Fungicide Applications in Annual Strawberry
}

\author{
R. W. Blacharski, University of Florida, Gulf Coast Research and Education Center-Dover, 13138 Lewis Gallagher \\ Road, Dover 33527; J. A. Bartz, University of Florida, Department of Plant Pathology, 1453 Fifield Hall, Gaines- \\ ville 32611-0680; and C. L. Xiao and D. E. Legard, University of Florida, Gulf Coast Research and Education \\ Center-Dover, 13138 Lewis Gallagher Road, Dover 33527
}

\begin{abstract}
Blacharski, R. W., Bartz, J. A., Xiao, C. L., and Legard, D. E. 2001. Control of postharvest Botrytis fruit rot with preharvest fungicide applications in annual strawberry. Plant Dis. 85:597602 .

The control of postharvest Botrytis fruit rot was evaluated during 1997-98 and 1998-99. Weekly applications of captan and thiram were examined at two or three different rates, respectively. Iprodione applications were combined with the captan and thiram treatments and also applied alone for two peak bloom periods. Strawberry fruit were harvested and graded twice weekly for marketable yield and preharvest incidence of Botrytis fruit rot. For postharvest evaluations, fruit from four harvests were selected and stored at $4^{\circ} \mathrm{C}$, and Botrytis fruit rot incidence was recorded over 14 days of storage. Fungicide treatments reduced the incidence of preharvest Botrytis fruit rot and increased marketable yield. The incidence of postharvest Botrytis fruit rot was significantly affected by harvest date, length of time in storage, and fungicide treatment. The highest rate captan and thiram treatments had the least Botrytis fruit rot and the longest storage life. Reduced-rate captan and thiram treatments generally did not provide the same control as their respective high-rate treatments. Iprodione added to either the captan or thiram treatments did not consistently reduce the preharvest or postharvest incidence of Botrytis fruit rot or increase yield. Regular, full-rate fungicide treatments appear to be necessary to control Botrytis fruit rot in Florida and to provide the storage life necessary to reach distant markets.
\end{abstract}

Additional keywords: Fragaria ananassa, gray mold

Botrytis fruit rot, caused by Botrytis cinerea, is the most important preharvest disease of strawberry in Florida (12). This disease is also an important postharvest concern, since apparently healthy fruit develop lesions during shipping and storage, causing severe losses $(6,7,24)$. Control of this disease in harvested strawberries is critical because minor amounts of fruit decay can make a shipment unmarketable. According to the current USDA grade 1 standard, decay from pathogenic microorganisms cannot exceed $2 \%$ of visible fruit defects. This standard is often exceeded in shipments inspected for grade compliance (6). If a lot fails to meet grade, the grower suffers significant losses due to reduction in price or rejection of the shipment.

Corresponding author: Daniel E. Legard E-mail: legard@ufl.edu

Current address of C. L. Xiao: Washington State University, Tree Fruit Research and Extension Center, Wenatchee, WA 98801.

Florida Agricultural Experiment Station Journal Series No. R-07968.

Accepted for publication 13 February 2001.

Publication no. D-2001-0322-01R

(C) 2001 The American Phytopathological Society
Botrytis fruit rot is initiated in the field (2). B. cinerea sporulates on senescent foliage, which constitutes the principle source of inoculum in perennial strawberry production systems (3). Additional conidia are produced on diseased flowers and fruit (16). These conidia are important secondary sources of inoculum in annual production systems that feature multiple, overlapping flowering and harvesting cycles. Sporulation on infected plant tissue (25) and infection of flowers are favored by cool, wet conditions (5). Conidia may be dispersed to flowers by wind, water (26), or harvesting operations. Petals and stamens are colonized, and the fungus penetrates into developing fruit $(4,21)$. The resulting infections usually become quiescent, with pathogen development resuming during or after the fruit ripen. Few fruit are infected through direct contact with spores, either in the field or during postharvest handling (26). Sommer et al. (24) suggested that most Botrytis fruit rot that developed in cross-country shipments arose from quiescent infections initiated in the field.

Since Botrytis fruit rot infections are established before harvest, effective control of this disease must begin in the field (15). The application of fungicides is important in the management of Botrytis fruit rot. More money is spent on fungicide applica- tions for strawberries than for any other vegetable crop in Florida (22). Protectant fungicides, such as captan, are usually applied on a 7-day schedule throughout the growing season. Captan is the industry standard and is applied up to the maximum 24 times per season at 2.3 to $3.4 \mathrm{~kg}$ a.i./ha. Despite such measures, marketable yields are still reduced by 5 to $15 \%$ on susceptible cultivars (13). Fungicides with greater efficacy against $B$. cinerea, such as iprodione, are typically applied during peak bloom periods to reduce floral infections in both perennial (29) and annual production systems (14).

In perennial strawberry, the effect of preharvest fungicide applications on postharvest Botrytis fruit rot has been described in several studies. Captan and thiram applied during a peak bloom period and once on the developing fruit reduced postharvest Botrytis rot for 16 days but not 21 days after the last application (18). Smith and Worthington (23) found that four field applications of thiram or one application during full bloom had no effect on postharvest Botrytis fruit rot on strawberries stored for 3 days. Maas and Smith (17) found that incidence of postharvest Botrytis fruit rot in plots treated with three benomyl applications on a 10-day schedule beginning at first bloom was not significantly different from untreated plots after 3 days of storage. All of these studies involved a limited number of preharvest applications and ambient temperature $\left(20^{\circ} \mathrm{C}\right)$ storage conditions.

Preharvest fungicide applications may control postharvest Botrytis fruit rot more effectively in annual strawberry production systems than in perennial systems. Aharoni and Barkai-Golan (1) observed up to $29 \%$ less Botrytis fruit rot among fruit stored for 10 days at $2^{\circ} \mathrm{C}$ if the plants had been treated with iprodione, metameclam, or captafol on a 7-day schedule as compared with untreated plants. Even at ambient temperature storage, $75 \%$ less Botrytis fruit rot occurred among strawberries stored for 3 days if the plots had been treated with thiram on a 7-day application schedule compared with untreated plots (28).

The objectives of this study were to determine the effect of preharvest fungicide treatments of captan or thiram, with or without bloom applications of iprodione, 
on the development of Botrytis fruit rot among annual strawberries produced in Florida and then stored under conditions common in commercial handling.

Field plots and treatments. Experiments were conducted at the Gulf Coast Research and Education Center-Dover (GCREC-Dover), University of Florida, during the 1997-98 and 1998-99 seasons. izer at $570 \mathrm{~kg} / \mathrm{ha}$ and fumigation with a mixture of methyl bromide and chloropicrin (98:2) at $350 \mathrm{~kg} / \mathrm{ha}$. Canadian-grown, green-top transplants of the cultivar Sweet Charlie were planted in plastic-mulched, raised beds on $1.22-\mathrm{m}$ centers $(71 \mathrm{~cm}$ wide, $18 \mathrm{~cm}$ high at the center, and $15 \mathrm{~cm}$ high at the edge). Each plot consisted of 16 plants arranged in two staggered rows within a single bed. Plants were spaced $30 \mathrm{~cm}$ apart within and between rows. Overhead sprinkler irrigation was used for 14 days to establish the transplants. Subsequent irrigation and fertilizer applications were applied through drip lines.

Treatments included combinations of different rates of captan and thiram with and without bloom applications of iprodione (Table 1) and were arranged in a randomized complete block design with four replications. After establishment, captan and thiram applications were initiated on a 7-day schedule and continued until the final harvest (Table 1). Treatments were applied with a backpack $\mathrm{CO}_{2}$ sprayer at a rate of 935 liters/ha. Iprodione was applied twice during each of the first two peak bloom periods each season on 18 and 26 November 1997 and 14 and 21 January 1998 in the first season and on 18 and 25

\section{MATERIALS AND METHODS} Land preparation began in the fall with a broadcast application of 6:2:8 starter fertil-

November and 23 and 30 December 1998 in the second season. Two-spotted spider mites and insect pests were controlled with standard pesticide applications.

Preharvest evaluations for Botrytis fruit rot and yield. In 1997-98, all ripe and diseased fruit were harvested and graded twice weekly from 1 December to 12 March. In 1998-99, all fruit were harvested twice a week, but only graded once a week, from 1 December to 9 March. Fruit were separated into marketable and unmarketable categories. Marketable fruit were counted and weighed, and unmarketable fruit were sorted into the number of fruit with Botrytis fruit rot and other defects. Total marketable yield and incidence of preharvest Botrytis fruit rot were calculated as treatment means for the whole season.

Postharvest evaluations for Botrytis fruit rot. Fruit were collected on 16 and 23 February and 2 and 9 March in 1997-98 and on 22 January, 26 February, and 5 and 9 March in 1998-99. Marketable fruit were hand harvested into 1-liter plastic clamshell containers. Within $2 \mathrm{~h}$ of harvest, fruit were forced-air cooled in a $1{ }^{\circ} \mathrm{C}$ cold room with a custom-built, small-scale forced-air cooler unit. The unit created a pressure drop of $128 \mathrm{~Pa}$ over the strawberries, which pulled room air through the stacked flats at a flow rate of $0.07 \mathrm{~m}^{3} \mathrm{~s}^{-1}$. After $40 \mathrm{~min}$, the average pulp temperature reached $3^{\circ} \mathrm{C}$. Fruit were stored in a walk-in cold room and covered with empty flats to minimize water loss until transport to the Postharvest Laboratory at Gainesville. Following the last cooling treatment, fruit containers were placed in 144-liter ice chests precooled to $1^{\circ} \mathrm{C}$, and Blue ice packages (Rubbermaid Co., Wooster, $\mathrm{OH}$ ) were added to maintain storage tempera-

Table 1. Effect of fungicide treatment on preharvest incidence of Botrytis fruit rot and marketable yield of strawberry fruit for 1997-98 and 1998-99

\begin{tabular}{|c|c|c|c|c|}
\hline \multirow[b]{2}{*}{ Treatment $^{\mathrm{v}}$} & \multicolumn{2}{|c|}{ 1997-98 } & \multicolumn{2}{|c|}{ 1998-99 } \\
\hline & Botrytis $(\%)^{\mathrm{w}}$ & Yield $(g)^{x}$ & Botrytis (\%) & Yield (g) \\
\hline Captan $80 \mathrm{~W}$ (3.4 kg a.i./ha) full rate & $11.7 \mathrm{a}$ & $5,026 \mathrm{a}^{\mathrm{y}}$ & $13.7 \mathrm{bc}$ & $2,006 \mathrm{abc}$ \\
\hline Captan $80 \mathrm{~W}$ full rate + iprodione & $13.7 \mathrm{a}$ & $4,978 \mathrm{a}$ & $14.8 \mathrm{bcd}$ & $1,811 \mathrm{c}$ \\
\hline Captan $80 \mathrm{~W}$ (2.5 kg a.i./ha) 3/4 rate & $14.8 \mathrm{a}$ & $3,988 \mathrm{~b}$ & $20.7 \mathrm{de}$ & $2,120 \mathrm{abc}$ \\
\hline Captan 80W 3/4 rate + iprodione & $12.2 \mathrm{a}$ & $4,724 \mathrm{a}$ & $12.9 \mathrm{ab}$ & $1,972 \mathrm{bc}$ \\
\hline Captan $80 \mathrm{~W}$ (1.7 kg a.i./ha) $1 / 2$ rate & $\ldots$ & $\ldots^{\mathrm{z}}$ & $14.9 \mathrm{bcd}$ & $2,287 \mathrm{ab}$ \\
\hline Captan 80W $1 / 2+$ iprodione & $\ldots$ & $\ldots$ & $15.3 \mathrm{bcd}$ & $2,161 \mathrm{abc}$ \\
\hline Thiram $65 \mathrm{WP}$ (2.9 $\mathrm{kg}$ a.i/ha) high rate & $\ldots$ & $\ldots$ & $13.8 \mathrm{bc}$ & $2,414 \mathrm{a}$ \\
\hline Thiram 65WP high rate + iprodione & $\ldots$ & $\ldots$ & $12.3 \mathrm{a}$ & $2,174 \mathrm{abc}$ \\
\hline Thiram (1.8 kg a.i./ha) low rate & $26.2 \mathrm{~b}$ & $3,815 \mathrm{~b}$ & $\ldots$ & $\ldots$ \\
\hline Thiram low rate + iprodione & $12.4 \mathrm{a}$ & $4,049 \mathrm{~b}$ & $\ldots$ & $\ldots$ \\
\hline Iprodione bloom only & $26.2 \mathrm{~b}$ & $3,122 \mathrm{c}$ & $\ldots$ & $\ldots$ \\
\hline Untreated control & $35.3 \mathrm{c}$ & $2,223 \mathrm{~d}$ & $21.5 \mathrm{e}$ & $1,783 \mathrm{c}$ \\
\hline
\end{tabular}

${ }^{v}$ Captan and thiram were applied on a 7-day schedule at rates indicated. Supplemental applications of iprodione and the iprodione-alone treatment were applied four times at a rate of $1.1 \mathrm{~kg}$ a.i./ha. For 1997-98, iprodione was applied on 18 and 26 November and 14 and 21 January, and for 199899 it was applied on 18 and 25 November and 23 and 30 December.

${ }^{w}$ Botrytis fruit rot incidence was arcsine square root transformed prior to analysis; values reported are nontransformed means for the whole season.

${ }^{x}$ Mean weight of marketable fruit harvested from four plots (replicates).

${ }^{y}$ Numbers followed by the same letter within each column are not significantly different according to Fisher's protected LSD $(P \leq 0.05)$. Each value is the mean of four harvests.

${ }^{z} \ldots=$ not tested during the season. tures during the 2-h transit to Gainesville. During one of the trips, fruit temperatures were monitored with a thermocouple. The fruit temperature at the time of transfer from the ice-chest to the cold room at Gainesville was $4^{\circ} \mathrm{C}$. The fruit containers were transferred into covered, cardboard flats in a walk-in cold room and stored at $4^{\circ} \mathrm{C}$ and $95 \%$ relative humidity for 2 weeks.

Beginning on day 3 in storage and continuing every subsequent day in storage, the entire contents of each fruit container were inspected for the incidence of Botrytis fruit rot based on brown discoloration, presence of white mycelium, or presence of sporulation. Visual diagnosis was confirmed by examination of sporulation with a hand lens or by plating aerial mycelium on acidified potato dextrose agar. Disease assessments were conducted in the cold room to minimize water condensation on the surface of the fruit or the clamshell container. Decayed fruit were left in the clamshell containers to replicate commercial conditions and to prevent damage and spread of inoculum that would accompany excessive handling. Fruit were observed for storage durations of 11 (1997-98) or 14 days (1998-99).

Statistical analysis. The preharvest and postharvest incidences of Botrytis fruit rot (incidence of Botrytis fruit rot per total number of fruit) were transformed by arcsine square root prior to analysis. Total marketable yield was calculated from cumulative totals for harvests from the whole season. Analysis of variance was performed on preharvest Botrytis fruit rot incidence and marketable yield. Mean separations were made by Fisher's protected $\operatorname{LSD}(P \leq 0.05)$. The variation in incidence of postharvest Botrytis fruit rot was analyzed over the whole storage interval and reported at storage intervals that are significant in commercial production. Five days represents the typical time from harvest to arrival at distribution centers, 7 to 10 days represents arrival at markets and purchase by the consumer, and 11 to 14 days represents the maximum practical storage interval. Repeated measures analyses of variance were performed using the SAS general linear models (GLM) procedure (release 6.11, SAS Institute, Cary, NC) with the repeated option. Time interactions were tested using Wilks' $\lambda$ (13). When harvest date and treatment interactions were significant, analyses of variance for each harvest were performed separately. Treatment means were separated with Fisher's protected LSD $(P \leq 0.05)$. Linear contrast analyses were conducted to provide a more detailed evaluation of treatment differences.

Climatic conditions. General precipitation and temperature data were continuously monitored by a weather station (Adcon Telemetry, Boca Raton, FL) at GCREC-Dover. Thirty-year averages were 
calculated from weather data collected at the same location from 1965 to 1995.

\section{RESULTS}

Preharvest Botrytis fruit rot and marketable yield. All fungicide treatments significantly reduced Botrytis fruit rot compared with the untreated control in both years, except for the captan 3/4rate treatment in 1998-99 (Table 1). The highest incidence of Botrytis occurred in the untreated control both seasons. The incidence of Botrytis in the fungicide treatments in 1997-98 was similar to that found in 1998-99; however, the incidence in the untreated control was $64 \%$ higher in 1997-98 than in 1998-99. The marketable yield from the fungicide treatments in 1998-99 was 60\% lower than in 199798. Yield from the untreated control in 1998-99 was 20\% lower than in 1997-98. All the fungicide treatments had significantly higher yields than the untreated control in 1997-98, whereas just two of eight fungicide treatments did so in 199899.

The lowest incidence of Botrytis fruit rot and highest marketable yield occurred in the full and reduced-rate captan with iprodione treatments in 1997-98 and the high-rate thiram treatments in 1998-99 (Table 1). The 3/4-rate captan treatment yielded significantly less than the full-rate captan treatment in 1997-98, but not in 1998-99. The addition of iprodione to the full-rate captan treatment did not reduce preharvest Botrytis or increase marketable yield compared with the full-rate captanonly treatment either season. The iprodione-only treatment and low-rate thiram treatment had the highest incidence of Botrytis among the fungicide treatments. The iprodione-only treatment had the lowest yield.

Postharvest Botrytis fruit rot. Repeated measures analysis of variance indicated that fungicide treatment significantly reduced the incidence of Botrytis fruit rot in storage both seasons (Table 2). In 199798 , a significant harvest $\times$ treatment interaction occurred $(P=0.0003)$, indicating that fungicide effects on postharvest incidence were dependent on the harvest date. Time (days in storage) and a time $\times$ harvest interaction significantly affected postharvest Botrytis $(P=0.0001)$ in both years (Table 2). The time $\times$ treatment interaction was significant $(P=0.0276)$ in 1998-99, but not in 1997-98.

Fungicide treatment effects on postharvest Botrytis fruit rot development in 1997-98 were analyzed separately by harvest date due to a significant treatment $x$ harvest interaction (Table 2). In each of the four postharvest samples, the incidence of Botrytis was significantly affected by treatment. The untreated control always had the highest incidence of Botrytis when significant differences were present among the treatments (Table 3). When the incidence of Botrytis fruit rot was moderate to high (harvests 1 and 3), some fungicide treatments significantly reduced Botrytis incidence compared with the untreated control. However, when the incidence of Botrytis fruit rot was relatively low (harvests 2 and 4), fungicide treatments did not reduce the incidence of Botrytis. The fullrate captan treatment and reduced-rate captan with iprodione treatment provided the best control. However, none of the treatments consistently had the lowest incidence of Botrytis for all four harvest dates.

In 1998-99, there was no interaction between treatment and harvest on postharvest Botrytis fruit rot development; therefore, the four postharvest samples were combined for analysis (Table 4). The full-rate captan and high-rate thiram treatments consistently had a significantly lower incidence of Botrytis than the untreated control at each storage interval. The captan- or thiram-only treatments had similar levels of Botrytis in storage compared with their respective treatments combined with the iprodione bloom applications. The captan reduced-rate treatments, with and without iprodione, did not consistently reduce the incidence of Botrytis compared with the control. The untreated control had the highest incidence of Botrytis at each storage interval analyzed.

Four applications of iprodione targeted on the first two peak blooming periods did not consistently reduce postharvest Botrytis fruit rot (Table 3). Compared with the untreated control, the iprodione-only treatment reduced the incidence of Botrytis in fruit sampled during the third harvest and after 8 to 11 days in storage. Of 36 possible direct comparisons of treatment, harvest, and storage interval on the addition of iprodione bloom applications to either a captan or a thiram schedule, only one significantly reduced the incidence of Botrytis fruit rot. Less Botrytis developed from the combined thiram and iprodione treatment for harvest 3 in 1997-98. An orthogonal contrast of captan treatments with and without iprodione treatments identified two significant differences in the incidence of Botrytis in storage (Tables 3 and 4). The captan full and $3 / 4$ rate plus iprodione treatments had less Botrytis than the captan alone treatments on day 11 of storage in the first harvest in 199798. Unexpectedly, in 1998-99, an orthogonal contrast of Botrytis incidence among the captan with or without iprodione treatments revealed a significant increase in the incidence of Botrytis associated with the addition of iprodione to captan only on day 5 .

Weather conditions. The weather conditions during the two seasons of the experiment were very different. Total precipitation was substantially higher than the 30year average $(3.9 \mathrm{~cm})$ during 1997-98 $(10.7 \mathrm{~cm})$ and substantially lower during $1998-99(1.3 \mathrm{~cm})$. The average daily temperature was similar to the 30 -year average $\left(18.1^{\circ} \mathrm{C}\right)$ during $1997-98 \quad\left(18.3^{\circ} \mathrm{C}\right)$ but higher in $1998-99\left(19.8^{\circ} \mathrm{C}\right)$.

Table 2. Repeated measures analysis of variance describing effects of harvest date and fungicide treatment on postharvest Botrytis fruit rot development on strawberry fruit of Sweet Charlie during 1997-98 and 1998-99

\begin{tabular}{|c|c|c|c|c|c|c|c|c|}
\hline \multirow[b]{2}{*}{ Source of variation } & \multicolumn{3}{|c|}{ 1997-98 } & \multirow[b]{2}{*}{ Wilks' $\lambda$} & \multicolumn{3}{|c|}{ 1998-99 } & \multirow[b]{2}{*}{ Wilks' $\lambda$} \\
\hline & df & $\mathbf{M S}^{\mathbf{v}}$ & $P>F^{\mathbf{w}}$ & & df & MS & $P>F$ & \\
\hline Block & 3 & 0.2154 & 0.0029 & $\ldots{ }^{x}$ & 3 & 0.1452 & 0.3519 & $\ldots$ \\
\hline Harvest ${ }^{\mathrm{y}}$ & 3 & 1.1235 & 0.0001 & $\ldots$ & 3 & 0.6004 & 0.6004 & $\ldots$ \\
\hline Harvest $\times$ block $\left(\right.$ error $\left._{\mathrm{a}}\right)$ & 9 & 0.0530 & 0.2817 & $\ldots$ & 9 & 0.3684 & 0.0052 & $\ldots$ \\
\hline Treatment & 7 & 0.4351 & 0.0001 & $\ldots$ & 9 & 0.4159 & 0.0013 & $\ldots$ \\
\hline Harvest $\times$ treatment & 21 & 0.1231 & 0.0003 & $\ldots$ & 30 & 0.1263 & 0.5364 & $\ldots$ \\
\hline Residual (error ${ }_{b}$ ) & 83 & 0.0427 & $\ldots$ & $\ldots$ & 120 & 0.1319 & $\ldots$ & $\ldots$ \\
\hline \multicolumn{9}{|l|}{ Time effects } \\
\hline Day $^{z}$ & 8 & $\ldots$ & 0.0001 & 0.1247 & 11 & .. & 0.0001 & 0.1466 \\
\hline Day $\times$ harvest & 24 & $\ldots$ & 0.0001 & 0.1875 & 33 & $\ldots$ & 0.0001 & 0.2831 \\
\hline Day $\times$ treatment & 56 & $\ldots$ & 0.7085 & 0.5446 & 110 & $\ldots$ & 0.0276 & 0.3074 \\
\hline Day $\times$ harvest $\times$ treatment & 168 & $\ldots$ & 0.5512 & 0.1551 & 330 & $\ldots$ & 0.0161 & 0.0488 \\
\hline
\end{tabular}

v Mean square.

${ }^{\text {w }}$ Significant probability values associated with $F$ tests.

$\mathrm{x} \ldots=$ not determined.

y Harvests in 1997-98 made on 16 and 23 February and 2 and 9 March. Harvests in 1998-99 made on 22 January, 26 February, and 5 and 17 March.

${ }^{z}$ Days in storage at $4^{\circ} \mathrm{C}$. Botrytis fruit rot incidence observed over 8 days in 1997-98 and 11 days in 1998-99. 


\section{DISCUSSION}

The high-rate captan or thiram treatments on a 7-day schedule produced the highest marketable yield and the lowest incidence of preharvest and postharvest Botrytis fruit rot. The reduced rate captan or thiram treatments, iprodione bloom only treatment, and the untreated control had significantly lower marketable yields and a higher incidence of Botrytis. Combining iprodione with weekly captan or thiram treatments did not consistently improve control of Botrytis over captan or thiram treatments alone. Regular preharvest fungicide treatments extended the time that fruit complied with current grade standards for defects due to disease and provided the storage life necessary for commercial production.

Botrytis fruit rot is initiated in the field as flower infections $(4,21)$, and fungicide treatments that protect flowers from infection by $B$. cinerea are essential to reduce preharvest disease (15). Fungicide treatments that reduce the incidence of preharvest Botrytis fruit rot should also reduce postharvest disease. In this study, fungicide treatments that reduced the incidence of preharvest Botrytis compared with the untreated control also reduced postharvest disease. Conversely, when no reduction occurred in preharvest Botrytis, there was no reduction in postharvest Botrytis. However, fungicides will not control postharvest Botrytis fruit rot if proper storage conditions are not maintained. After harvest, the control of Botrytis derived from fungicide treatment is maintained by rapid cooling of the fruit and cold storage near $1{ }^{\circ} \mathrm{C}(19,27)$.
Fruit from the fungicide treatments are more likely to remain disease-free for a longer storage interval than fruit from the untreated control. In this study, untreated fruit often failed to meet U.S. Grade 1 standards less than 3 days after harvest (R. W. Blacharski, unpublished data). Regular fungicide treatments extended the time fruit remained in grade by an average of 2 to 3 days over untreated fruit. Control of Botrytis fruit rot early in the storage interval is important because fruit are often shipped by truck to distant markets in the eastern United States and Canada. Whole- salers can refuse to accept shipments that have more than $2 \%$ decay upon arrival (U.S. Grade 1 standard). Rejection of a shipment can result in serious financial losses for both grower and wholesaler (6). Consumers are also reluctant to purchase fruit that have visible disease, even if the shipment passes market inspection. Since 5 days is the typical interval between harvest and arrival at market, controlling postharvest Botrytis rot for 5 or more days is critical for the successful marketing of strawberry fruit. Currently, this control is achieved by preharvest fungicide applica-

Table 4. Effect of preharvest fungicide treatment on the development of Botrytis fruit rot on strawberry fruit of Sweet Charlie during 2 weeks of storage at $4^{\circ} \mathrm{C}$ for $1998-99$

\begin{tabular}{|c|c|c|c|c|}
\hline \multirow[b]{2}{*}{ Treatment $^{w}$} & \multicolumn{4}{|c|}{ Botrytis fruit rot incidence $(\%)^{v}$} \\
\hline & Day $5^{x}$ & Day 7 & Day 10 & Day 14 \\
\hline 1. Captan (3.4 kg a.i./ha) full rate & $1.9 \mathrm{a}^{\mathrm{y}}$ & $3.1 \mathrm{a}$ & $5.3 \mathrm{a}$ & $17.2 \mathrm{ab}$ \\
\hline 2. Captan full rate + iprodione & $3.9 \mathrm{abc}$ & $5.2 \mathrm{abc}$ & $8.2 \mathrm{ab}$ & $22.7 \mathrm{bc}$ \\
\hline 3. Captan (2.5 kg a.i./ha) $3 / 4$ rate & $3.0 \mathrm{abc}$ & $5.7 \mathrm{abc}$ & $8.1 \mathrm{ab}$ & $23.2 \mathrm{bc}$ \\
\hline 4. Captan $3 / 4$ rate + iprodione & $4.3 \mathrm{bc}$ & $7.7 \mathrm{bc}$ & $12.2 \mathrm{bc}$ & $26.5 \mathrm{bc}$ \\
\hline 5. Captan (1.7 kg a.i./ha) $1 / 2$ rate & $3.5 \mathrm{abc}$ & $4.8 \mathrm{ab}$ & $9.6 \mathrm{abc}$ & $20.7 \mathrm{bc}$ \\
\hline 6. Captan $1 / 2$ rate + iprodione & $4.5 \mathrm{bc}$ & $5.8 \mathrm{abc}$ & $10.8 \mathrm{abc}$ & $26.8 \mathrm{bc}$ \\
\hline 7. Thiram $(2.9 \mathrm{~kg}$ a.i./ha $)$ high rate & $2.5 \mathrm{ab}$ & $3.3 \mathrm{a}$ & $5.5 \mathrm{a}$ & $10.3 \mathrm{a}$ \\
\hline 8. Thiram high rate + iprodione & $2.8 \mathrm{ab}$ & $3.9 \mathrm{ab}$ & $6.4 \mathrm{ab}$ & $14.9 \mathrm{ab}$ \\
\hline 9. Untreated control & $5.7 \mathrm{c}$ & $9.8 \mathrm{c}$ & $15.1 \mathrm{c}$ & $32.2 \mathrm{c}$ \\
\hline \multicolumn{5}{|l|}{ Linear contrast $\left(P>F^{z}\right)$} \\
\hline $1+3+5$ vs. $2+4+6$ & 0.0229 & 0.0867 & 0.0859 & 0.1061 \\
\hline
\end{tabular}

${ }^{\mathrm{v}}$ Botrytis fruit rot incidence was transformed arcsine square root prior to analysis. Values reported are actual means for four harvests.

${ }^{\mathrm{w}}$ Captan and thiram treatments were applied weekly at rates indicated. Supplemental applications of iprodione and the iprodione-only treatment applied four times at a rate of $1.1 \mathrm{~kg}$ a.i./ha on November 18 and 25 and December 23 and 30

${ }^{x}$ Days in storage at time of evaluation.

${ }^{\mathrm{y}}$ Numbers followed by the same letter within a column are not significantly different according to Fisher's protected LSD $(P \leq 0.05)$.

${ }^{\mathrm{z}}$ Significant probability values associated with the $F$ test from orthogonal linear contrasts.

Table 3. Effect of preharvest fungicide treatment on the development of Botrytis fruit rot on strawberry fruit of Sweet Charlie during 11 days of storage at $4^{\circ} \mathrm{C}$ from four different harvests during the $1997-98$

\begin{tabular}{|c|c|c|c|c|c|c|c|c|c|c|c|c|}
\hline \multirow[b]{3}{*}{ Treatment $^{\mathrm{w}}$} & \multicolumn{12}{|c|}{ Botrytis fruit rot incidence $(\%)^{\mathrm{u}}$} \\
\hline & \multicolumn{3}{|c|}{ Harvest one ${ }^{v}$} & \multicolumn{3}{|c|}{ Harvest two } & \multicolumn{3}{|c|}{ Harvest three } & \multicolumn{3}{|c|}{ Harvest four } \\
\hline & Day $5^{x}$ & Day 8 & Day 11 & Day 5 & Day 8 & Day 11 & Day 5 & Day 8 & Day 11 & Day 5 & Day 8 & Day 11 \\
\hline $\begin{array}{l}\text { 1. Captan }(3.4 \mathrm{~kg} \\
\text { a.i./ha) full rate }\end{array}$ & $1.2 \mathrm{a}^{\mathrm{y}}$ & $8.6 \mathrm{ab}$ & $13.9 \mathrm{abc}$ & $1.8 \mathrm{a}$ & $3.8 \mathrm{a}$ & $6.4 \mathrm{ab}$ & $6.4 \mathrm{abc}$ & $9.9 \mathrm{a}$ & $15.9 \mathrm{ab}$ & $1.5 \mathrm{ab}$ & $5.1 \mathrm{ab}$ & $7.7 \mathrm{a}$ \\
\hline $\begin{array}{l}\text { 2. Captan full rate } \\
+ \text { iprodione }\end{array}$ & $1.4 \mathrm{a}$ & $4.0 \mathrm{a}$ & $5.3 \mathrm{ab}$ & $1.0 \mathrm{a}$ & $4.1 \mathrm{a}$ & $12.4 \mathrm{abc}$ & $5.4 \mathrm{abc}$ & $8.1 \mathrm{a}$ & $9.6 \mathrm{~A}$ & $0.7 \mathrm{a}$ & $1.1 \mathrm{a}$ & $6.1 \mathrm{a}$ \\
\hline $\begin{array}{l}\text { 3. Captan }(2.5 \mathrm{~kg} \\
\text { a.i./ha) } 3 / 4 \text { rate }\end{array}$ & $4.0 \mathrm{a}$ & $9.1 \mathrm{ab}$ & $11.6 \mathrm{abc}$ & $2.9 \mathrm{a}$ & $6.2 \mathrm{a}$ & $14.5 \mathrm{bc}$ & $1.1 \mathrm{a}$ & $8.1 \mathrm{a}$ & $18.3 \mathrm{ab}$ & $2.5 \mathrm{ab}$ & $2.5 \mathrm{ab}$ & $6.4 \mathrm{a}$ \\
\hline $\begin{array}{l}\text { 4. Captan } 3 / 4 \text { rate } \\
\text { + iprodione }\end{array}$ & $1.2 \mathrm{a}$ & $3.5 \mathrm{a}$ & $3.5 \mathrm{a}$ & $2.5 \mathrm{a}$ & $3.4 \mathrm{a}$ & $15.8 \mathrm{c}$ & $2.6 \mathrm{a}$ & $10.0 \mathrm{a}$ & $14.4 \mathrm{ab}$ & $3.5 \mathrm{ab}$ & $4.7 \mathrm{ab}$ & $9.1 \mathrm{a}$ \\
\hline $\begin{array}{l}\text { 5. Thiram }(1.8 \mathrm{~kg} \\
\text { a.i./ha) low rate }\end{array}$ & $1.8 \mathrm{a}$ & $5.6 \mathrm{a}$ & $8.9 \mathrm{ab}$ & $2.1 \mathrm{a}$ & $3.1 \mathrm{a}$ & $5.3 \mathrm{a}$ & $11.2 \mathrm{bcd}$ & $18.2 \mathrm{~b}$ & $22.7 \mathrm{~B}$ & $5.6 \mathrm{~b}$ & $6.3 \mathrm{~b}$ & $11.1 \mathrm{a}$ \\
\hline $\begin{array}{l}\text { 6. Thiram low rate } \\
+ \text { iprodione }\end{array}$ & $2.4 \mathrm{a}$ & $11.7 \mathrm{abc}$ & $16.2 \mathrm{bc}$ & $2.9 \mathrm{a}$ & $8.5 \mathrm{a}$ & $14.0 \mathrm{bc}$ & $3.2 \mathrm{ab}$ & $8.8 \mathrm{a}$ & $10.8 \mathrm{~A}$ & $2.5 \mathrm{ab}$ & $3.6 \mathrm{ab}$ & $7.5 \mathrm{a}$ \\
\hline $\begin{array}{l}\text { 7. Iprodione bloom } \\
\text { only }\end{array}$ & $3.0 \mathrm{a}$ & $24.8 \mathrm{c}$ & $27.3 \mathrm{c}$ & $2.7 \mathrm{a}$ & $7.2 \mathrm{a}$ & $8.3 \mathrm{abc}$ & $15.3 \mathrm{~cd}$ & $26.0 \mathrm{~b}$ & $26.0 \mathrm{~B}$ & $4.3 \mathrm{ab}$ & $6.1 \mathrm{~b}$ & $12.1 \mathrm{a}$ \\
\hline $\begin{array}{l}\text { 8. Untreated con- } \\
\text { trol }\end{array}$ & $4.3 \mathrm{a}$ & $21.3 \mathrm{bc}$ & $24.1 \mathrm{c}$ & $4.3 \mathrm{a}$ & $5.7 \mathrm{a}$ & $14.6 \mathrm{bc}$ & $17.5 \mathrm{~d}$ & $42.9 \mathrm{c}$ & $51.2 \mathrm{C}$ & $3.8 \mathrm{ab}$ & $5.2 \mathrm{ab}$ & $6.6 \mathrm{a}$ \\
\hline \multicolumn{13}{|c|}{ Linear contrast $\left(P>F^{\mathrm{z}}\right)$} \\
\hline $1+3$ vs. $2+4$ & 0.2504 & 0.0800 & 0.0250 & 0.5418 & 0.6084 & 0.1891 & 0.7452 & 0.9750 & 0.1215 & 0.9191 & 0.3639 & 0.9326 \\
\hline
\end{tabular}

" Botrytis fruit rot incidence was arcsine square root transformed prior to analysis; values reported are actual means.

${ }^{v}$ Fruit harvested on 16 February (harvest one), 23 February (harvest two), 2 March (harvest three), and 9 March (harvest four).

${ }^{\mathrm{w}}$ Captan and thiram treatments were applied weekly at rates indicated. Supplemental applications of iprodione and the iprodione-only treatment applied four times at a rate of $1.1 \mathrm{~kg}$ a.i./ha on November 18 and 25 and December 23 and 30.

${ }^{x}$ Days in storage at time of evaluation.

y Numbers followed by the same letter within a column are not significantly different according to Fisher's protected LSD $(P \leq 0.05)$.

${ }^{\mathrm{z}}$ Significant probability values associated with the $F$ test from orthogonal linear contrasts. 
tions and the maintenance of proper storage conditions.

Full-rate fungicide treatments generally reduced the incidence of preharvest and postharvest Botrytis fruit rot and increased marketable yield compared with the reduced-rate fungicide treatments and the untreated control. In both years, reduced rates of captan or thiram did not reduce preharvest or postharvest Botrytis, similar to the full- rate treatments. Moreover, total marketable yield was not consistently equivalent to the yields obtained with fullrate treatments. In perennial systems, repeated applications of fungicides at high rates may not be as important, since disease pressure is often lower and there are usually only four or five harvests from a single bloom period each season (29). In annual production, there are several flowering periods and harvests over several months, and inoculum is produced on diseased fruit (16). Full-rate fungicide treatments appear to be necessary to protect flowers and fruit from infection by $B$. cinerea under environmental conditions in Florida. Despite the level of control achieved with full-rate treatments, preharvest losses still averaged at least $12 \%$. This suggests that if reduced-rate treatments of captan or thiram are used, preharvest and postharvest losses are likely to be higher than with full-rate treatments.

The incidence of Botrytis fruit rot increased with the length of time in cold storage. This effect is typical for strawberry (19), and the incidence of decay can increase quickly, especially toward the end of the storage period (24). After harvest, strawberry fruit soften and senesce, promoting the growth of previously quiescent $B$. cinerea infections $(8,10)$. Nesting, where the mycelium growing on infected fruit penetrates into adjacent fruit, also causes an increase in fruit infections late in storage (11). As expected, harvest date and treatment interacted with time in storage on the incidence of Botrytis fruit rot. Fruit collected from each harvest developed under different environmental conditions and probably had different background levels of Botrytis infection. Fungicide treatments would also reduce the preharvest incidence of Botrytis fruit rot, contributing to variation in postharvest disease progress. Such effects would change the rate of disease progress in storage among the harvests, resulting in interactions between day (time in storage), harvest date, and treatment.

Based on control of Botrytis fruit rot and marketable yield, thiram is a potential alternative to captan. Captan is commonly used to control preharvest Botrytis fruit rot because it can be applied weekly and fruit can be picked 1 day after application. Currently, thiram can be applied every 10 days and fruit can be picked 3 days after application. In field studies, thiram provided control of Botrytis fruit rot similar to that of other compounds $(9,18)$. In the present study, the high-rate treatments of captan and thiram had equivalent reductions in the incidence of Botrytis fruit rot and marketable yields in 1998-99, but not in 1997-98. In 1997-98, thiram was applied at half the rate used in 1998-99 (high rate) and did not control Botrytis as well as the captan treatment. Comparisons of the thiram highrate treatment with the full-rate captan treatment should be based on the results of several seasons. However, the efficacy of thiram in these experiments suggests that thiram may be used as an alternative to captan when the label-allowed 24 applications of captan are insufficient due to the length of the season or higher disease pressure.

In perennial production systems, just two fungicide applications during the peak bloom period reduced Botrytis fruit rot as well as applications made throughout the season (29). In this study, iprodione applications made during the first two peak bloom periods reduced preharvest Botrytis fruit rot and increased marketable yield compared with the untreated control in the 1997-98 season. However, the control achieved was less than in the other seasonlong fungicide programs tested. In annual production systems, additional applications of $B$. cinerea-specific fungicides (i.e., iprodione) to a weekly fungicide schedule are made during peak bloom periods. In this study, this strategy enhanced preharvest disease control only occasionally and only with the reduced rate captan or thiram treatments. Some postharvest benefit was observed for reduced-rate captan and thiram treatments in 1997-98, but not in 1998-99. It was expected that iprodione would not provide postharvest control of Botrytis in 1998-99. Abnormally high field temperatures caused an early second bloom period that produced few marketable fruit (R. W. Blacharski, unpublished data). The fruit used in the postharvest evaluations were collected from a third bloom period and were not treated with iprodione due to a limit of four applications each season imposed by the fungicide label. More research is needed to evaluate the efficacy of additional bloom applications of fungicides for control of Botrytis fruit rot in annual production.

Preharvest fungicide applications control postharvest Botrytis fruit rot and extend the storage life of strawberry fruit within U.S. Grade 1 standards. However, concern over the effect of fungicide residue on food quality, human health, and environmental quality make it prudent to reduce fungicide usage. Typically, untreated fruit would not pass grade standards within 3 days of harvest and therefore could not be marketed. Alternative control methods are needed to replace or reduce fungicide use for the control of Botrytis. Modified cultural practices, such as protected culture (30) or selection of resistant cultivars $(13,20)$, may reduce the need for fungicides to control Botrytis fruit rot.

\section{ACKNOWLEDGMENTS}

We thank D. J. Mitchell, F. Martin, J. C Mertley, D. Wenzel, S. Staton, J. Sumler, L. Smith, N. Moore, and C. Manley for their valuable assistance during this study.

\section{LITERATURE CITED}

1. Aharoni, Y., and Barkai-Golan, R. 1987. Preharvest fungicide sprays and polyvinyl wraps to control Botrytis rot and prolong the postharvest storage life of strawberries. J. Hortsci. 62:177-181.

2. Braun, P. G., and Sutton, J. C. 1987. Inoculum sources of Botrytis cinerea in fruit rot of strawberries in Ontario. Can. J. Plant Pathol. 9:1-5.

3. Braun, P. G., and Sutton, J. C. 1988. Infection cycles and population dynamics of Botrytis cinerea in strawberry leaves. Can. J. Plant Pathol. 10:133-141.

4. Bristow, P. R., McNicol, R. J., and Williamson, B. 1986. Infection of strawberry flowers by Botrytis cinerea and its relevance to grey mould development. Ann. Appl. Biol. 109:545-554.

5. Bulger, M. A., Ellis, M. A., and Madden, L. V. 1987. Influence of temperature and wetness duration on infection of strawberry flowers by Botrytis cinerea and disease incidence of fruit originating from infected flowers. Phytopathology 77:1225-1230.

6. Ceponis, M. J., and Butterfield, J. E. 1973 The nature and extent of retail and consumer losses in apples, oranges, lettuce, peaches, strawberries and potatoes marketed in greater New York. U.S. Dep. Agric. Mark. Res. Rep. 996.

7. Ceponis, M. J., Cappellini, R. A., and Lightner, G. W. 1987. Disorders in sweet cherry and strawberry shipments to the New York market, 1972-1984. Plant Dis. 71:472-475.

8. Hortynski, J. A. 1991. The problem of gray mold in strawberry breeding. Pages 54-56 in: The Strawberry into the 21 st Century. A. Dale and J. L. Luby, eds. Timber Press, Portland OR.

9. Howard, C. M., Chandler, C. K., and Albregts, E. E. 1991. Evaluation of fungicides for the control of Botrytis fruit rot and fruit anthracnose, 1990. Fungic. Nematicide Tests 46:105.

10. Kader, A. A. 1991. Quality and its maintenance in relation to the postharvest physiology of the strawberry. Pages $145-152$ in: The Strawberry into the 21 st Century. A. Dale and J. L. Luby, eds. Timber Press, Portland, OR.

11. Legard, D. E., Chandler, C. K., and Bartz, J. A. 1997. The control of strawberry diseases by sanitation. Acta Hortic. 439:917-921.

12. Legard, D. E., Widden, A. J., and Chandler, C. K. 1997. Incidence and occurrence of strawberry diseases in Florida from 1991-1996. Adv. Strawberry Res. 16:35-47.

13. Legard, D. E., Xiao, C. L., Mertely, J. C., and Chandler, C. K. 2000. Effects of plant spacing and cultivar on incidence of Botrytis fruit rot in annual strawberry. Plant Dis. 84:531-538.

14. Legard, D. E., Xiao, C. L., Mertely J. C., and Chandler, C. K. 2000. Management of Botrytis Fruit Rot in annual winter strawberry using captan, thiram, and iprodione. Plant Dis. 85:31-39.

15. Maas, J. L. 1980. Postharvest diseases of strawberry. Pages 329-353 in: The Strawberry. N. F. Childers, ed. Horticultural Publications, Gainesville, FL

16. Maas, J. L. 1984. Fungal diseases of the fruit. Pages 56-57 in: Compendium of Strawberry Diseases. American Phytopathological Society, St. Paul, MN

17. Maas, J. L., and Smith, W. L. 1972. Prehar- 
vest fungicide treatments for increasing yields and controlling preharvest and postharvest fruit decay of strawberry. Plant Dis. Rep. 56:296-299.

18. Miller, P. M., and Stoddard, E. M. 1959. Control of grey mold on strawberries. Plant Dis. Rep. 43:646-648.

19. Mitchell, F. G., Maxie, E. C., and Greathead, A. S. 1964. Handling strawberries for fresh market. University of California, Oakland.

20. Olcott-Reid, B., and Moore, J. N. 1995. Field reactions of strawberry cultivars and selections to anthracnose fruit rot, leather rot, and gray mold in Arkansas. Fruit Var. J. 49:4-13.

21. Powelson, R. L. 1960. Initiation of strawberry fruit rot caused by Botrytis cinerea. Phytopathology 50:491-494.

22. Smith, S. A., and Taylor, T. G. 1996. Production costs for selected vegetables in Florida.
University of Florida, Cooperative Extension Service, Circ. 1146.

23. Smith, W. L., and Worthington, J. T. 1965. Reduction of postharvest decay of strawberries with chemical and heat treatments. Plant Dis. Rep. 49:619-623.

24. Sommer, N. F., Fortlage, R. J., Mitchell, F. G., and Maxie, E. C. 1973. Reduction of postharvest losses of strawberry fruits from Botrytis fruit rot. J. Am. Soc. Hortic. Sci. 98:285-288.

25. Sosa-Alvarez, M., Madden, L. V., and Ellis, M. A. 1995. Effects of temperature and wetness duration on sporulation of Botrytis cinerea on strawberry leaf residues. Plant Dis. 79:609-615.

26. Sutton, J. C. 1990. Epidemiology and management of Botrytis leaf blight of onion and Botrytis fruit rot of strawberry: A comparative analysis. Can. J. Plant Pathol. 12:100-110.
27. Talbot, M. T., and Chau, K. V. 1991. Precooling strawberries. Florida Cooperative Extension Service. IFAS. Circ. 942. University of Florida, Gainesville.

28. Washington, W. S., Shanmuganathan, N., and Forbes, C. 1992. Fungicide control of strawberry fruit rots, and the field occurrence of resistance to Botrytis cinerea to iprodione, benomyl and dichlofluanid. Crop Prot. 11:355-360.

29. Wilcox, W. F., and Seem, R. C. 1994. Relationship between strawberry gray mold incidence, environmental variables, and fungicide applications during different periods of the fruiting season. Phytopathology 84:264-270.

30. Xiao, C. L., Chandler, C. K., Price, J. F., and Legard, D. E. 1999. Comparative study on epidemics of strawberry fruit diseases unde plastic tunnel and field production systems in Florida. (Abstr.) Phytopathology 89:S86. 